\title{
A Fashionable Mask: Branded Value Proposition During the Coronavirus Pandemic
}

\author{
Victoriya Larchenko \\ National Technical University "Kharkiv Polytechnic Institute”, Ukraine
}

\section{Abstract}

The coronavirus pandemic has changed not only the social, economic, political spheres of nations, but also fashion industry, having to cancel fashion shows. Fashion brands started offering value proposition changed under new conditions to give the value to their customers with changing needs. A lot of fashion brands follow their pandemic sustainable business strategy to help medical staff with masks, gowns, and sanitizers for free, to donate to medical organizations, coronavirus research in Universities' laboratories that also increases their economic value added (EVA). A mask takes mostly two functions - utilitarian and emotional, i.e. new technological and fashionable part of the mask production/consumption. There are creative ideas in mask making by technological brands like a self-cleaning mask, collaborations of high-tech companies and fashion industry representatives, fashion brands creating fashionable masks by using double sustainable business strategy, popculture brands creating masks with their branded themes, fashion brands creating cloth masks made of the latest trends, artists creating unique masks using artisan techniques, a technological and fashionable mix like facerecognition masks, and also politicians setting up mask trends. The fashion brand analysis shows that the value proposition is based on value increase in EVA during the coronavirus pandemic, because they understand the necessity of sustainable business strategy to gain the longer-term customer loyalty.

Keywords: mask, fashion, brand, value proposition, coronavirus, sustainable business strategy, new technologies

\section{Introduction}

The rise of coronavirus turned out unexpectedly to the biggest part of the world officially announced by China on December 31, 2019. However, later scientists and other research attempts have found its evidences in both China and Europe before its official announcement in autumn and even summer 2019. Medicine, economies and other spheres did not know how to react to the unknown aggressive virus and what measures are the best to be taken. The world needed to adapt to new realities by social distance, mask, lockdown, attempts to overcome economic crisis and so on. 
Some countries provided financial support for businesses, e.g. the UK (Financial Support, 2020), Canada (COVID-19, 2020). Nevertheless, a lot of businesses, small in particular, had to be closed. However, some of them tried to overview their business model not to be forced into bankruptcy. They understood the necessity to provide value proposition to both meet changing needs of their customers and use the opportunity to attract new ones. Value proposition was to go online, to offer the things connected with protection against COVID-19 as well as to inspire mood of the customers. Fashion industry is the one that quite successfully offered its value proposition to customers.

\section{Literature Review}

As COVID-19 is still a new phenomenon there is not much information about it in scientific literature except medical one, a few of political and economic topics (e.g. Balasubramanian, 2020; Gans, 2020; Maller, 2020; Qu et al., 2020; Saxena, 2020). There can hardly be found scientific works dedicated to the coronavirus and fashion. However, there is much information about it on media, mostly online magazines, newspapers, fashion brand websites and social media.

E.g. Ivan Allegranti (Allegranti, 2020) articulates fashion show holding in main fashion capitals in February 2020 by wearing masks while e.g. the government of Italy was more conscious to adopt the Decree Law "Decreto Cura Italia" (March 17, 2020) according to which measures were taken to overcome economic crisis in the state because of the coronavirus. Allegranti researched the Italian coronavirus case, when the first Italian fashion brand Armani cancelled its Fall-Winter 2020-2021 runway show for the audience for safety reasons turning the show into closed-door and using new technologies to stream it on both its website and social networks (Maitland, 2020). Later other Italian fashion brands followed the Armani's strategy (Allegranti, 2020). They are Moncler (Moncler Genius 2020, February 23, 2020 Milan (https://www.facebook.com/events/viale-molise-70-20137-milano-miitalia/moncler-genius-2020-cancellation-public-opening/907891382962332)), Laura Biagiotti (https://www.shutterstock.com/ru/editorial/image-editorial/laurabiagiotti-show-runway-fall-winter-2020-milan-fashion-week-italy-23-feb-2020$10565130 \mathrm{~g}$ ), etc. Other non-Italian brands have also joined the former to cancel their shows in Italy like Michael Kors' 007 capsule collection (Petrarca, 2020). Italian fashion brands like Max Mara, Prada, Versace, Gucci canceled their May cruise shows outside Italy beforehand in April 2020 (Turk, 2020).

Sarah Jones states that fashion companies during the coronavirus pandemic are to use the opportunity for sustainability balanced within their corporate social responsibility as "eco-friendly innovation could actually build more resilient business over the long term" (Jones, 2020).

Jasmin Malik Chua (Chua, 2020) analyzes the circular-economy commitment signed by a lot of companies in the fashion industry elaborated by the Ellen McArthur Foundation (https://www.ellenmacarthurfoundation.org/assets/downloads/emf- 
joint-statement.pdf) expressing the idea of the necessity of sustainable business strategies for businesses especially in the conditions of the coronavirus pandemic: "policymakers, CEOs, and other influential individuals are highlighting the circular economy as a solution to build back better in response to the economic impact of the coronavirus pandemic" (https://www.ellenmacarthurfoundation.org/news/morethan-50-global-leaders-pledge-to-build-back-better-with-the-circular-economy).

\section{Methodology}

The methodological basis for the paper research is the VARS model elaborated by Deepak Somaya (the "Business Strategy" course. University of Illinois at UrbanaChampaign, https://www.coursera.org/learn/strategy-business).

The four interconnected elements of the VARS business model are:

1. value proposition;

2. activities-resources-capabilities;

3. realization/revenue model;

4. scope of enterprise.

There are a lot of definitions of value proposition. E.g., "the value proposition or offering of the company depicts which value it intends to deliver to its customers" (Nielsen and Lund: 54).

The value in value proposition, which meets the current needs of the customers, leads to company ROI, hence success, measured by an analytical tool called economic value added (EVA). The tool was developed by Bennett Stewart III and Joel Stern in 1982 (Grant, 2003: 1-2) and is still widely used.

The main idea of value proposition is to offer such a value to customers, which develops a new business model so that EVA will show the profitability of the brand. There are three types of EVA in a new business model (Figure 1):

- value is increased;

- costs are decreased;

- value is increased, while costs are decreased.

The last type is the best for the profitability of the company. Modern new technological companies use this type of EVA in their value proposition. They are Netflix, Google, etc. 


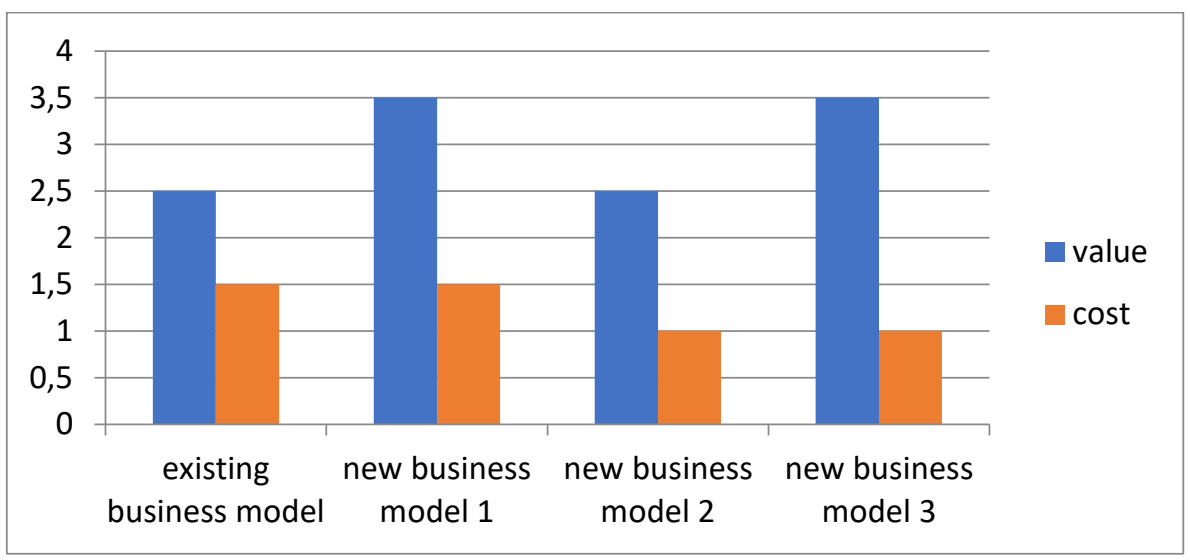

Figure 1 - Economic Value Added

In the paper there have been analyzed fashion brands to find out which type of EVA has mostly been used among them during the coronavirus pandemic.

In this paper the value proposition of a fashion brand during the coronavirus pandemic means the value the fashion brand delivers to its customers by sustainable business strategy within the COVID-19 conditions by means of supplying 1) medical staff with free medical masks, gowns and 2) customers with fashionable masks to meet their basic emotions: fear and happiness.

\section{Fashion Brands and Sustainable Business Strategy During the Coronavirus Pandemic}

Fashion brands understand the necessity to participate in social campaigns during the coronavirus pandemic to strengthen their image. They have two ways to do that: 1) to help medical staff with free masks, medical gowns, etc. and 2) to donate to buy necessary equipment, medicines, etc.

\section{Fashion Brands and Their Free Products}

Sophie Warburton stated that "fashion and philanthropy aren't two words commonly associated with one another, although many of the industry's leaders have quietly donated generously in the past. If the film The Devil Wears Prada is anything to go by, the public perception is that the fashion industry is superficial, materialistic, and self obsessed. But in the wake of Covid-19 the fashion world has shown signs of change." (Warburton, 2020). The same idea is expressed by Ellen Millard: "The luxury industry often gets a hard time for being frivolous, but its efficient and philanthropic response to the coronavirus pandemic has provided vital aid on the front line." (Millard, 2020).

Fashion brands of different countries have tried to help medical staff first of all by supplying them with hand sanitizers, masks and gowns for free. Such fashion brands are: 1) the French luxury conglomerate LVMH producing hand sanitizers on its perfume and makeup production lines commonly producing cosmetic and perfume 
goods for Givenchy, Christian Dior, and Guerlain to give those hydroalcoholic gels of 12 tons of its initial batch to French health authorities for free (Allaire, 2020; 0'Kane, 2020) because of its shortage during the coronavirus pandemic (Allaire, 2020; George-Parkin, 2020); 2) Bulgari, the Italian jeweler brand, collaborated with ICR, "its perfume partner" to produce " $75 \mathrm{ml}$ recyclable bottles" of hand sanitizers of "several hundreds of thousands" to "be distributed to medical facilities through ... Italian Civil Protection Department" (Millard, 2020); 3) Ralph Lauren has produced 25.000 face masks along with 25.000 gowns (Millard, 2020); 4) Giorgio Armani switched its each factory in Italy to produce disposable medical overalls for medical staff (Millard, 2020); 5) Prada has produced 110.000 masks and 80.000 gowns for medical staff, "using a breathable, non-woven propylene fabric" as the assistance to reply to the Tuscany region's calling for help in shortage of masks and gowns for medical staff (Millard, 2020; Samaha, 2020); 6) Gap Inc. along with its partners producing gowns and masks for the front line medical staff (Yates, 2020); 7) Inditex, the Zara owner, has offered masks for both patients and medical staff, which it thinks is the priority in Spain (Yates, 2020) and also medical fabric for gowns (Bobb, 2020); 8) Gucci has made 55.000 medical gowns and over 1 million masks (Samaha, 2020); 9) H\&M has produced "personal protective equipment" to be distributed among medical staff round the world (Samaha, 2020); 10) Eugenia Kim, a luxury hat and accessories designer from New York City, on perceiving the needs of the front line medical staff, after call for help by New York City governor Andrew M. Cuomo and also her Chinese hat factories having produced masks before, understood her facilities were enough to produce masks for medical staff up to 50.000 a day (George-Parkin, 2020); 11) other small US fashion brands like Collina Strada, Christian Siriano have produced masks for medical staff in New York (Bramley, 2020).

\section{Fashion Brands and Donations}

Some fashion brands sell fashionable masks to spend some part of the profit on donation against the coronavirus (Tobin, 2020). Some others donate money, e.g. 1) Giorgio Armani has donated 2 million euros to Italian hospitals and institutions (Millard, 2020); 2) "Versace made a contribution of about 144 thousand dollars to the Chinese Red Cross Foundation" (Turk, 2020); 3) Dolce and Gabbana had previously partnered with the Italian medical school, Humanitas University, and will continue working with them in the hopes of "finding a cure." (Petrarca, 2020); 4) LVMH donated 1.9 million pounds to the Chinese branch of the Red Cross Society in January, and also it gave 40 million surgical and face masks having been ordered in China to medical staff in France (Millard, 2020; Bramley, 2020); 5) Bulgari donated to the Spallanzani hospital (Italy) (Millard, 2020) to purchase a new microscope to research the coronavirus (Samaha, 2020), 6) Moncler donated 10 million euros for the hospital construction in Milan to treat those who suffer from COVID-19 (Bramley, 2020; Samaha, 2020); 7) Gucci donated in different crowdfunding campaigns against COVID-19 and organized \#GucciCommunity by "asking fans to make a donation to the WHO's initiative, along with giving the agency complete access to its social media 
channels in the hopes of amplifying official public service information" (Samaha, 2020); 8) Ralph Lauren donated not only to different foundations that help struggle against the coronavirus, but also "gifted an undisclosed amount to the CFDA/Vogue Fashion Fund to help fashion designers hit by the economic downturn. 'We believe that no matter who you are or where you are from, we are all connected.... That is why we are taking significant action to help our teams and communities through this crisis."' (Samaha, 2020); 9) Burberry has funded the University of Oxford coronavirus vaccine research and also donated The Felix Project and FareShare to feed those in need with meals (Samaha, 2020); 10) Bottega Veneta has provided "two-year scholarships across the cities of Veneto, Lazio, and Campania" in Italy to research the coronavirus (Samaha, 2020); 11) Dolce\&Gabbana has collaborated with Sofia Vergara, the Colombian American actress, in the "Amore for Scientific Research" campaign hashtagged as \#DGFATTOACASA (Made at Home) with the brand's artisans' digital workshops to unite and welcome creativity while experiencing the lockdown (Rougeau, 2020) that "celebrates life and the beauty of Italy" (Samaha, 2020) adding "The whole world and all of our lives will never be the same again. We truly hope that all of this will lead to a rebirth and want to do our part so that all of us, especially future generations, can one day benefit from these fundamental scientific discoveries" (Bonagofsky, 2020) with the Devotion bag online sales some portion of which is to be donated to the COVID-19 research conducted by Humanitas University (Samaha, 2020; Bonagofsky, 2020), and also the brand has collaborated with INTESA San Paolo Bank "to facilitate crowdfunding" and be guaranteed that no commission will be charged out of the donation to the University (Rougeau, 2020).

\section{A Mask: New Technologies and/or Fashion}

A lot of companies are attempting to elaborate sustainable business strategy during the coronavirus pandemic to offer value proposition as, from one hand, an innovative technologies introduction in mask creation and production to medical staff as the priority and its customers, from the other hand, a fashionable mask offer to customers as the priority.

There are a lot of creative technological ideas with face masks. E.g. 1) a self-cleaning mask being disinfected under the heat of its carbon fibre inner layer by charging via its USB port connected to a standard cellphone charger for about half an hour innovated at Technion University, Haifa, Israel (Amchay, Harash et al., 2020); 2) a transparent pool mask to protect a swimmer from the coronavirus in a pool innovated by a Japanese sports company Konami Sports for the opening of pools in Japan on June 1, 2020 (Joy, 2020); 3) a ClearMask "without hiding your face" preventing from miscommunication was initially developed for medical staff and later for common customers who have some disabilities (https://www.theclearmask.com/product).

Politicians introduce fashion of masks to the public. The first one is the president of Slovakia Zuzana Čaputová who "swore in the new government wearing a matching outfit, complete with a color-coordinated face mask" making "fashion history" 
(Rabimov, 2020); Japanese Chief Cabinet Secretary Yoshihide Suga who promotes the Ainu issues had a face mask with the Ainu print during a press conference, made by "an embroidery circle in Noboribetsu, Hokkaido", which got 500 orders at once and was not in time to fulfill all of them as it can make only 20 masks per day (Kyodo News, 2020).

Fashion brands create fashionable cloth face masks that "concurrent with a wave of designers who have chosen to repurpose their archival fabrics for new creations, Silvia Tcherassi's team brings back a familiar gingham print that criss-crossed her spring/summer '20 collection", combined with charity from the mask sales to Every Mother Counts (Cohen, 2020); Polka dot masks by GetUsPPE, being of an on-trend print (Cohen, 2020); Wisteria face Mask by the Vampire's Wife being of an on-trend color and print (Cohen, 2020).

Artists create fashionable and/or unique masks. E.g. Ýrúrarí, a Reykjavik knitting designer who adds knit 3D face elements to second-hand sweaters, applied her creative ideas to knit face mask, but she does not sell them, the opposite she has offered the patterns (https://www.yrurari.com/shop/digital-sleik-zine) for those who can knit to do it by themselves and calm down during the pandemic, moreover Ýrúrarí adds that this masks seem freaky thus it may cause social distance from others (Kraus, 2020).

Popculture brands create masks with their branded themes. E.g. Disney, which donates its proceeds to Med Share and also it has donated " 1 million cloth face masks for children and families in underserved and vulnerable communities across the U.S., which will be distributed by Med Share. And due to overwhelming demand, the company has already reached its goal of raising \$1 million in profits." (Johns, 2020).

Fashion brands create fashionable masks by using double sustainable business strategy. E.g. Brocade Mask by VPL, a sustainable brand, that cuts masks from vintage Japanese obi belts, traditionally worn over kimonos on formal occasions like wedding and also donating proceeds to the Fashion Girls For Humanity initiative and "For every four masks purchased, one isolation medical gown will be donated to" medical staff (Cohen, 2020).

There are collaborations of high-tech companies and fashion industry representatives to create masks. E.g. an AI company Anywear and a model Halima Aden created hijabwearing masks for Arab medical female staff (Davis, 2020; Okwodu, 2020).

There are masks that meet both needs - technological and fashionable. E.g. Danielle Baskin, a San Francisco designer, established a Maskalike company that prints a customer's face or any meme on the protective face masks (https://maskalike.com), the idea based on her meeting the need of unlocking a smartphone with a facial recognition technology feature that became a problem because of a face mask on, based on a 3D-technology calling herself a maker of a "trendy dystopian product" and adding "The combination of the coronavirus, facial recognition on our phones, fear of 
surveillance, and late-stage capitalism really struck a chord with the internet. ... The most surprising thing to me is how this spread globally so quickly. People in South Korea, Latvia, France, and China reached out to me within a few days. ... Whether it's a wildfire, a virus, or a protest, I realise humans all over the world right now can relate to the symbol of the mask." (Facial-recognition Mask, 2020); Custom Face Mask as an opportunity to have the print as the customer wants by uploading the file with the preferable print on the Customishop website and also describing the idea in the box for the company's graphic designer to contact the customer and discuss the details of the mask (https://customishop.com/product/custom-face-mask/); Donald Trump Loop-Cut Face Mask in the process of giving a speech (https://customishop.com/product/donald-trump-face-mask-loop-cut-respiratormask-filters-pm2-5) (Kyodo News, 2020).

\section{Conclusions}

To sum up, it is seen from the analysis of various fashion brands above; the value proposition they offer to customers is based on value increase in EVA during the coronavirus pandemic. It happens because they understand the necessity of sustainable business strategy to gain the customer loyalty for a longer term. The problem is to be studied further from more perspectives to understand what other value propositions can be elaborated in a business model for fashion brands to be successful under the pandemic.

\section{References}

[1] Allaire, Christian. (2020). LVMH Will Use Its Perfume Factories to Produce Hand Sanitizer. Vogue. https://www.vogue.com/article/lvmh-to-producehand-sanitizer-coronavirus.

[2] Allegranti Ivan. (2020). Fashion Law and Covid-19 as Seen through the Eyes of the Decree Law 17th March 2020. Proceedings of MAC 2020 in Prague, MAC Prague consulting Ltd.: Prague. Pp. 49-55.

[3] Amchay, Rami; Harash, Rinat et al. (2020). Self-cleaning Mask Can Kill Viruses with Heat from Phone Charger, Researchers Say. UK.Reuters.

https://uk.reuters.com/article/uk-health-coronavirus-israel-mask/selfcleaning-mask-can-kill-viruses-with-heat-from-phone-charger-researcherssay-idUKKBN23011J.

[4] Balasubramanian, M. (2020) Covid 19 - The New Age Pandemic. Chetpet Chennai: Notion Press.

[5] Bobb, Brooke. (2020). Zara Owner Inditex Will Donate Masks for Coronavirus Parents and Health Workers in Spain. Vogue.

https://www.vogue.com/article/zara-inditex-coronvirus-masks-hospitalgowns.

[6] Bonagofsky, Bree. (2020). Dolce \& Gabbana Launches Campaign to Help Fight Coronavirus. New York Post. https://nypost.com/2020/05/05/dolcegabbana-launches-campaign-to-help-fight-coronavirus. 
[7] Bramley, Ellie Violet. (2020). Prada the Latest Fashion Brand to Make Medical Face Masks. The Guardian.

https://www.theguardian.com/fashion/2020/mar/24/prada-the-latestfashion-brand-to-make-medical-face-masks.

[8] Christian Nielsen and Morten Lund eds. (2012). Business Models: Networking, Innovating and Globalizing. Ventus Publishing ApS. 186 p.

[9] Chua, Jasmin Malik. (2020). H\&M, Inditex Reaffirm Circular Economy Commitments Amid COVID-19 Pandemic. Sourcing Journal. https://sourcingjournal.com/topics/sustainability/ellen-maccarthurfoundation-coronavirus-circular-economy-h-m-inditex-stella-216220.

[10] Cohen, Jaclyn Alexandra. (2020). Fashion Brands Making Cloth Masks You Can Buy Now. Harper's Bazaar.

https://www.harpersbazaar.com/fashion/trends/g32192171/fashionbrands-masks-coronavirus.

[11] COVID-19: Relieffor your business. (2020). Export Development Canada. https://www.edc.ca/en/campaign/coronavirus-covid-19.html.

[12] Davis, Jessica. (2020). Halima Aden helps to Create Face Masks for Hijabwearing Frontline Workers. Harper's Bazaar.

https://www.harpersbazaar.com/uk/fashion/fashionnews/a32868099/halima-aden-face-masks-hijab-wearing-frontlineworkers.

[13] Facial-recognition Mask Let Wearers Unlock Their Phones. (2020). Dezeen. https://www.dezeen.com/2020/02/27/face-recognition-masks-restingrisk-face.

[14] Financial Support for Businesses during Coronavirus (COVID-19). (2020). Gov.uk. https://www.gov.uk/government/collections/financial-support-forbusinesses-during-coronavirus-covid-19.

[15] Gans, Joshua. (2020). Economics in the Age of COVID-19. Cambridge, MA: MIT Press. $160 \mathrm{p}$.

[16] George-Parkin, Hilary. (2020). Factories That Used to Make Perfume, T-shirts, and Cars are Now Making Supplies to Fight the Coronavirus. Vox. https://www.vox.com/the-goods/2020/4/6/21207135/factories-facemasks-ventilators-hand-sanitizer-coronavirus-manufacturing.

[17] Grant, James L. (2003). Foundations of Economic Value Added. $2^{\text {nd }}$ ed. Hoboken, New Jersey: John Wiley \& Sons, Inc. 194 p.

[18] Johns, Nikara. (2020). From "Star Wars" to "Frozen," the Best Disney Face Masks for Adults to Buy Now. Footwear News.

https://footwearnews.com/2020/shop/womens/disney-face-masks-adultsrelease-info-1202995076.

[19] Jones, Sarah. (2020). How Sustainability Fits into Fashion's COVID-19 Survival Plans. Sourcing Journal.

https://sourcingjournal.com/topics/sustainability/sustainable-apparelcoalition-coronavirus-recovery-global-fashion-agenda-210758. 
[20] Joy, Joel. (2020). Japanese Engineers Have Developed a Mask for the Pool. News USA. https://newsusa.website/japanese-engineers-have-developed-amask-for-the-pool.

[21] Kraus, Rachel. (2020). Monstrously Fun Knit Masks Encourage Social Distancing. Mashable. https://mashable.com/article/knitted-face-masktongue-lips.

[22] Kyodo News. (2020). Face Masks Embroidered with Indigenous Ainu Designs Popular in Japan. Kyodo News.

https://english.kyodonews.net/news/2020/05/1a0051ff3057-ainudesigned-face-masks-become-popular-in-japan-amid-virus-crisis.html.

[23] Maitland Hauley (2020). Giorgio Armani Cancels His AW20 Show Due To Coronavirus fear Within Italy. Vogue.

https://www.vogue.co.uk/news/article/giorgio-armani-cancels-showcoronavirus.

[24] Maller, Santosh. (2020). A Quick Guide to Impact of COVID 19 on Financial Reporting. New Yok: Bloomsbury Publishing. 366 p.

[25] Millard, Ellen. (2020). How Luxury Brands are Responding to COVID-19. Luxury London. https://luxurylondon.co.uk/style/hers/luxury-fashionbrands-respond-to-coronavirus.

[26] O'Kane Caitlin. (2020). LVMH, which owns luxury brands like Louis Vuitton and Christian Dior, will use perfume production lines to make hand sanitizer. CBS News. https://www.cbsnews.com/news/lvmh-hand-sanitizer-frenchluxury-brands-perfume-production-lines-france-louis-vuitton-company.

[27] Okwodu, Janelle. (2020). Halima Aden and Anywear Team Up to Create Masks for Hijab Frontline Workers. Vogue. https://www.vogue.com/article/halimaaden-anywear-collaboration-masks-interview.

[28] Petrarca, Emilia. (2020). Fashion in the Time of Coronavirus. The Cut. https://www.thecut.com/2020/02/coronavirus-milan-fashion-weekshows-canceled.html.

[29] Qu, Jie-Ming; Cao, Bin and Chen, Rong-Chang. (2020). COVID-19: The Essentials of Prevention and Treatment. London: Elsevier. 280 p.

[30] Rabimov, Stephan. (2020). Mask Diplomacy: When Function, Fashion, and Politics Intersect. Forbes.

https://www.forbes.com/sites/stephanrabimov/2020/03/26/maskdiplomacy-when-function-fashion-and-politics-intersect/\#ad899562ea2b.

[31] Rougeau, Naomi. (2020). Dolce And Gabbana Fund COVID_19 Research While Celebrating Italian Crafts. Elle.

https://www.elle.com/fashion/a32376216/dolce-and-gabbana.

[32] Samaha, Barry. (2020). The Fashion and Beauty Companies Helping to Compat the Effects of Coronavirus. Harper's Bazaar.

https://www.harpersbazaar.com/fashion/designers/a31901094/fashionbeauty-companies-coronavirus-donation. 
[33] Saxena, Shailendra K. (ed.). (2020). Coronavirus Disease 2019 (COVID-19): Epidemiology, Pathogenesis, Diagnosis, and Therapeutics. Singapore: Springer Nature Singapore Pte Ltd. 213 p.

[34] Tobin Sophie. (2020). How to match your mask to the rest of your look: four stylish outfits to try now. The Telegraph.

https://www.telegraph.co.uk/fashion/style/match-mask-rest-look-fourstylish-outfits-try-now/?li_source=LI\&li_medium=liftigniter-rhr.

[35] Turk, Robin (2020). The Impact of Coronavirus on the Fashion Industry. FashionUnited. https://fashionunited.uk/news/business/the-impact-ofcoronavirus-on-the-fashion-industry/2020031047905.

[36] Warburton, Sophie. (2020). How the fashion industry is rallying in the face of coronavirus. He Telegraph. https://www.telegraph.co.uk/luxury/womensstyle/week-fashion-gave-back-industry-rallying-face-coronavirus.

[37] Yates, Jacqueline Laurean. (2020). Milk Makeup, Gap Inc., Zara, and more brands giving back to coronavirus relief. Good Morning America. https://www.goodmorningamerica.com/style/story/lvmh-maker-louisvuitton-switches-making-hand-sanitizer-69619925. 